\title{
Quantitative and qualitative properties of giblets from conventional, organic, and wild ducks
}

\author{
Fouad Ali Abdullah Abdullah, Hana Buchtová \\ University of Veterinary Sciences Brno, Faculty of Veterinary Hygiene and Ecology, \\ Department of Animal Origin Food \& Gastronomic Sciences, Brno, Czech Republic
}

Received March 4, 2021

Accepted July 26, 2021

\begin{abstract}
The aim of the study was to evaluate selected properties of giblets (liver, heart, and gizzard) from conventional (C), organic (O), and wild (W) ducks. A total of 24 giblets (24 of each organ) were analysed in each bird group. Production properties, colour indicators, haem pigment content and chemical composition were compared. The heaviest organ with the highest yield was the liver in $\mathrm{C}$ and $\mathrm{W}$ ducks and the gizzard in $\mathrm{O}$ ducks $(P<0.05)$. The liver and gizzard of $\mathrm{W}$ and $\mathrm{O}$ ducks were darker $(P<0.05)$ compared to the same organs in $\mathrm{C}$ ducks. The redness of the heart of $\mathrm{O}$ ducks was higher $(P<0.05)$ than that of the heart of both other groups of ducks $(\mathrm{C}$ and $\mathrm{W})$. All $\mathrm{W}$ duck organs contained $(P<0.05)$ more haem pigment. The livers of reared ducks $(\mathrm{C}$ and $\mathrm{O})$ contained more protein $(P<0.05)$ than the livers of $\mathrm{W}$ birds. The liver of $\mathrm{C}$ reared poultry was about $3-4 \times$ fattier $(P<0.05)$ compared to the liver of the remaining two groups of ducks. The heart of wild ducks had the highest protein and lowest fat content, the heart of ducks from the $\mathrm{C}$ breeding system had the least protein, whereas ducks bred organically had the highest amount of fat in the heart. Ducks from the $\mathrm{O}$ system had a fattier gizzard compared to other birds $(P<0.05)$. The highest protein percentages were found in the gizzards of $\mathrm{W}$ ducks, the smallest in the gizzards of $\mathrm{C}$ poultry.
\end{abstract}

Edible viscera, poultry, chemical composition, wild birds, ecological system

Over the last two decades, world production of duck meat has increased (by around $67.2 \%$, from 2.91 to 4.86 million tonnes) more than production of goose and turkey meat (Kokoszynsk et al. 2020; FAOSTAT 2021). In the Czech Republic, consumption of duck meat per capita is around $0.8 \mathrm{~kg}$ (Zelenka 2014). The Czech Republic exported 2,834 metric tonnes of duck meat in 2020, whereas in 2019 it sold 3,889 tonnes which netted the exporter 18.09 million dollars. Exports of duck meat from the Czech Republic increased by 10.96\% between 2017 and 2019 (Anonymous 2021). According to Commission Regulation (EC) No. 543/2008, poultry carcasses are to be presented for sale with or without giblet. The same regulation indicates: "Giblets shall comprise the heart, neck, gizzard and liver, and all other parts considered as edible by the market on which the product is intended for final consumption. If the neck remains attached to the carcass, it is not considered as one of the giblets".

The yield of duck giblet (liver, heart, and gizzard) is around 5-7\% (Kolluri et al. 2015). In the last few decades, the amount of edible offal from slaughterhouses, meat processors and wholesalers has increased considerably (Darine et al. 2010). Duck giblets are used for the production of some traditional duck meat products such as foie gras (a popular French dish) and salted duck gizzards (consumed in Asia) (Biswas et al. 2019). Demand for edible poultry by-products is increasing due to their relatively cheap price, good nutritional value (low fat content) and fast preparation (Alvarez-Astorga et al. 2002; Seong et al. 2015).

Last year, the share of organic food compared to total consumption in the Czech Republic rose to $1.52 \%$. The government wants to increase this ratio to $4 \%$ by 2027 by means of

Address for correspondence:

Fouad Ali Abdullah Abdullah

Department of Animal Origin Food \& Gastronomic Sciences

Faculty of Veterinary Hygiene and Ecology

University of Veterinary Sciences Brno

Palackeho tr. 1946/1, 61242 Brno, Czech Republic 
a strategy facilitating market access for organic farms and by increasing consumer education (Šejnohová et al. 2021). The regulation of organic systems for poultry production, dealing with genotype, age, feeding and welfare, is explained in Commission Regulation (EC) No. 889/2008. The low share of organic food on the food market in the Czech Republic is attributed to its higher price in comparison with conventional food (Kowalska et al. 2020). These major price differences also pertain to the giblets of conventional, organic and wild ducks, for which reason providing the consumer with objective information about the nutritional value of these organs might be necessary.

The impact of the rearing system on the quantitative and qualitative properties of poultry meat has been confirmed by many studies (Castellini et al. 2002; Fanatico et al. 2007; Dou et al. 2009; Abdullah and Buchtová 2016; Abdullah and Buchtová 2017). Mancinelli et al. (2020) evaluated the influence of three different agroforestry systems on the meat properties of geese. The study found that grazing activity of geese in agroforestry systems enhanced by trees improved the qualitative properties (fatty acid and antioxidant content) of the goose meat. Organic system rules have been reported to have an influence on the quantitative and qualitative properties of chicken giblets. A difference has been observed in physicochemical properties between organic and conventional chicken giblets (Abdullah and Buchtová 2016).

The very lack of published information on this topic provided an incentive to undertake this study and make it available to readers, consumers, and researchers. The purpose of the present study was to evaluate and compare the production properties (weight and yield) and physicochemical properties (colour indicators, haem pigment content, and chemical composition) of giblets (liver, heart, and gizzard) from conventional, organic, and wild ducks.

\section{Materials and Methods}

Production properties

A total of 72 giblets from conventional (C), organic $(\mathrm{O})$, and wild $(\mathrm{W})$ ducks were evaluated in the study (24 gizzards, hearts, and livers from each evaluated group of ducks). Giblets and carcasses of $\mathrm{C}$ ducks were obtained from a conventional breeder system (Vodňanská Drůbež, a.s., Mirovice, Czech Republic). The properties of ducks from the conventional breeding system were as follows: Vodňanská Mladá breed, Anas platyrhynchos domesticus (Cherry Valley) hybrid, age at slaughter 45 days, carcass quality class A, a four-phase feeding programme including starter, grower 1 , grower 2 and finisher commercial feeding mixtures according to the producer's recommendations for the Cherry Valley SM3 hybrid.

$\mathrm{O}$ ducks (carcasses with giblets after being slaughtered and processed by the producer) were obtained from an organic breeder system (Ekofarma Bošina, Vernéřovice, Czech Republic). The properties of ducks from the organic breeding system were as follows: Anas platyrhynchos domesticus (White Pekin) hybrid, age at slaughter around 7 months, carcass quality class A (uncalibrated), fed a mixture of Bio BR1 and BR2 (Mikrop Čebín a.s., Čebín 416, 66423 Čebín, Czech Republic) (own mixture of oats and hybrid cereal triticale) as well as free-range grazing.

W ducks were obtained from the hunting staff of Mendel University in Brno, Czech Republic. The binomial name of W ducks is Anas platyrhynchos. The carcass processing procedure for W ducks was conducted at the workplace of the authors' team at the Department of Animal Origin Food \& Gastronomic Sciences, University of Veterinary Sciences Brno. The ducks had predominantly fed on plant sources (aquatic plants, various kinds of grasses, seeds and fruits, beets, acorns, potatoes) and animal sources (reptiles, fish, frogs, mammals such as voles and mice and the remains of carcasses, particularly in summer and autumn).

The eviscerated carcass and giblets (liver, heart, and gizzard) were weighed and recorded, and yields were calculated according to Massuquetto et al. (2020). The yields of eviscerated carcasses were calculated as carcass weight relative to live weight, and giblet (liver, heart, and gizzard) yield as part weight relative to both live weight and carcass weight, and expressed as percentages.

\section{Colour analysis}

The colour of giblets $\left(n=24\right.$ /group) was detected after $24 \mathrm{~h}$ of storage at $+4{ }^{\circ} \mathrm{C}$. The colour indicators of lightness, L*; redness, $\mathrm{a}^{*}$; yellowness, $\mathrm{b}^{*}$; Chroma, $\mathrm{C}^{*}=\left(\mathrm{a}^{* 2}+\mathrm{b}^{* 2}\right)^{0.5}$; and hue, $\mathrm{h}^{\circ}=\tan ^{-1}\left(\mathrm{~b}^{*} / \mathrm{a}^{*}\right)($ Saláková et al. 2009) were measured on the raw external surfaces of liver and heart (avoiding white visceral fat on the base of heart) and the fresh cut of muscle tissue surfaces of the gizzard. Measurement of colour indicators was conducted according to the CIE $\mathrm{L}^{*} \mathrm{a} * \mathrm{~b} *$ system using a CM-5 spectrophotometer (Konica Minolta Sensing, 


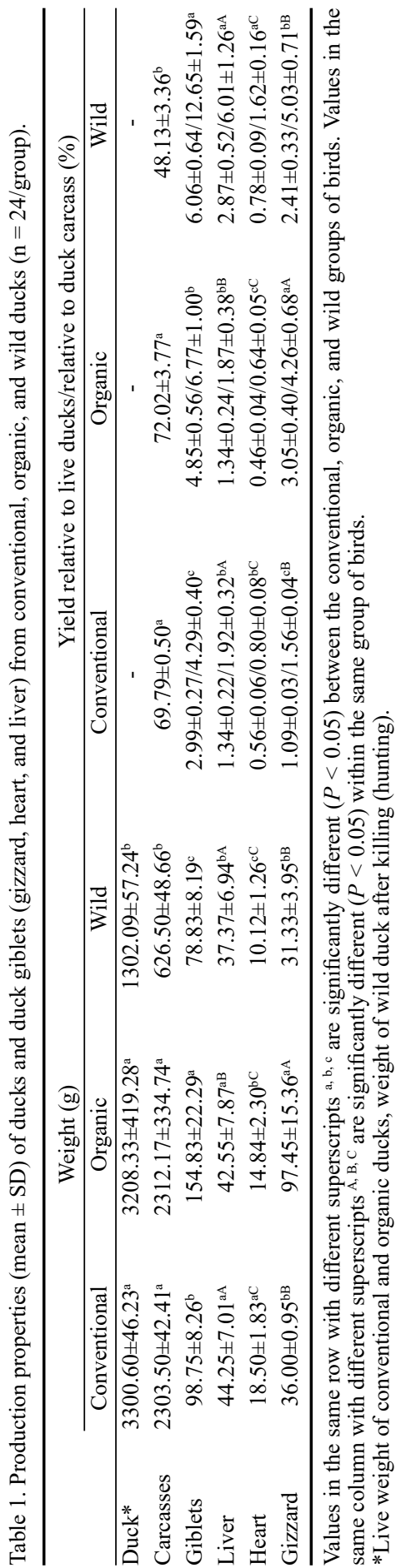

Inc., Japan). SpectraMagic NX Color Data Software was used to calculate the parameters, and the mean \pm SD of five measurements of each sample was reported.

\section{Chemical analysis}

Indicators of the basic chemical composition of giblets, comprised of gizzards, hearts, and livers from $\mathrm{C}, \mathrm{O}$, and $\mathrm{W}$ ducks were evaluated. In order to obtain an adequate amount of samples for all chemical analysis tests, giblets were homogenised together as one sample (liver 8 , heart 6 , gizzard 8 - mixed samples in total), and stored in a vacuum atmosphere at $-18{ }^{\circ} \mathrm{C}$ until analysed.

Dry matter determination was conducted gravimetrically by means of a drying process of samples for $24 \mathrm{~h}$ at $103 \pm 2{ }^{\circ} \mathrm{C}$ (ISO 1442 1997). Determination of total protein content was performed using a Kjeltec 2300 analyser (Foss Analytical AB, Hoganas, Sweden) according to ISO 937 (1978). Estimation of fat content was performed by sample analyses on a Soxtec 2055 (Foss Analytical AB, Hoganas, Sweden) with petrol ether as the extraction agent (ISO 1443 1973). Ash was estimated gravimetrically by burning the sample in a muffle oven (Elektro LM 212.11, Germany) at $550{ }^{\circ} \mathrm{C}$ until the disappearance of black carbon particles according to ISO 936 (1978). Carbohydrate was calculated mathematically by the subtraction of the total protein content + fat content + ash content from the dry matter content. The energy value $(\mathrm{kJ} / 100 \mathrm{~g})$ was estimated mathematically according to the formula (total protein content + carbohydrate content) $\times 17$ $+($ fat content $\times 37$ ) (conversion factors according to Regulation (EU) No. 1169/2011, Annex XIV). The content of haem pigment was estimated according to the Hornsey method, with measurement of absorbance at the $640 \mathrm{~nm}$ wavelength (Hornsey 1956; Izumimoto 1976).

\section{Statistical analysis}

Statistical analysis of the data was conducted using Microsoft Office Excel 2016. Statistical significance $(P<0.05)$ was determined by $t$-test and ANOVA analysis of variance, with post $h o c$ Tukey test to find differences between independent variances using UNISTAT 6.0 (Unistat ${ }^{\circledR}$ Limited, London, England).

\section{Results}

\section{Production properties}

Weights and yields of ducks and their giblets are shown in Table 1. No significant differences were observed between $\mathrm{C}$ and $\mathrm{O}$ ducks (live weight, carcass weight, and yield), whereas both ( $\mathrm{C}$ and O) had a significantly higher weight and yield than wild ducks. The hearts of the birds weighed the least, and the yield of the hearts was also the lowest $(P<0.05)$. The heaviest organ with the highest yield was the liver in $\mathrm{C}$ and $\mathrm{W}$ ducks and the gizzard in the group of $\mathrm{O}$ ducks $(P<0.05)$. The weight of the giblets from $\mathrm{O}$ ducks was higher compared to the giblets of $\mathrm{C}$ and $\mathrm{W}$ ducks, while the yield of giblets from $\mathrm{W}$ ducks was the highest. In spite of the fact that the livers of $\mathrm{C}$ and $\mathrm{O}$ were significantly $(P<0.05)$ heavier than those of $\mathrm{W}$ ducks, they had a significantly lower yield. The hearts of $\mathrm{W}$ ducks and the gizzards of O ducks had a higher yield and weight. 


\section{Colour indicators and haem pigment content}

Results for colour indicators and haem pigment content are shown in Table 2. The external surfaces of the liver and muscle tissue surfaces of the gizzard from $\mathrm{W}$ and $\mathrm{O}$ ducks were significantly $(P<0.05)$ darker (lower $\mathrm{L}^{*}$ value) than in the same organs from $\mathrm{C}$ ducks. The $\mathrm{L}^{*}$ value of the raw external surface of $\mathrm{W}$ duck hearts was significantly $(P<0.05)$ the lowest. Redness represented by the $\left(\mathrm{a}^{*}\right)$ value was significantly $(P<0.05)$ higher in the giblets (liver and gizzard) of $\mathrm{W}$ and $\mathrm{C}$ ducks than in $\mathrm{O}$ ducks. The values of redness in the hearts of W ducks were significantly $(P<0.05)$ higher that in the hearts of ducks from both $\mathrm{O}$ and $\mathrm{C}$ breeding systems. The livers of $\mathrm{C}$ ducks and hearts of $\mathrm{W}$ ducks were more yellow (higher $b^{*}$ values) than those of both other evaluated types of ducks. The muscles of the gizzard from $\mathrm{O}$ ducks were significantly $(P<0.05)$ less yellow than in the $\mathrm{C}$ and $\mathrm{W}$ ducks. The $\mathrm{C}^{*}$ values of giblets from $\mathrm{O}$ ducks were the lowest, as compared with $\mathrm{C}$ and $\mathrm{W}$ ducks.

\section{Chemical composition}

The chemical composition of giblets is presented in Table 3. The liver of ducks from the $\mathrm{O}$ production system have the highest total protein (significantly at $P<0.05$ in respect of W ducks) and ash content, and the lowest fat content (significantly at $P<0.05$ in respect of $\mathrm{C}$ duck) and energy value. The liver of $\mathrm{W}$ ducks contained a significantly $(P<0.05)$ larger

Table 2. Colour indicators and haem pigment content of giblets (mean $\pm \mathrm{SD}$ ) (gizzard, heart, and liver) from conventional, organic and wild ducks $(\mathrm{n}=24 /$ group $)$.

\begin{tabular}{|c|c|c|c|c|c|c|c|}
\hline Giblet & Type of duck & $\mathrm{L}^{*}$ & $a^{*}$ & $b^{*}$ & $\mathrm{C}^{*}$ & $\mathrm{~h}^{\circ}$ & $\mathrm{HP}\left(\mathrm{mg} \cdot \mathrm{g}^{-1}\right)$ \\
\hline & Conventional & $38.62 \pm 2.11^{\mathrm{a}}$ & $10.63 \pm 0.74^{\mathrm{a}}$ & $12.39 \pm 1.99^{\mathrm{a}}$ & $16.35 \pm 1.81^{\mathrm{a}}$ & $49.09 \pm 3.84^{\mathrm{a}}$ & $4.07 \pm 1.02^{\mathrm{b}}$ \\
\hline \multirow[t]{3}{*}{ Liver } & Organic & $33.02 \pm 2.51^{\mathrm{b}}$ & $8.40 \pm 1.40^{b}$ & $8.42 \pm 1.66^{\mathrm{b}}$ & $11.93 \pm 2.00^{\mathrm{b}}$ & $44.94 \pm 4.12^{\mathrm{a}}$ & $3.68 \pm 0.49^{b}$ \\
\hline & Wild & $30.70 \pm 4.51^{\mathrm{b}}$ & $11.39 \pm 2.24^{\mathrm{a}}$ & $8.56 \pm 3.21^{\mathrm{b}}$ & $14.36 \pm 3.47^{\mathrm{a}}$ & $35.74 \pm 7.52^{\mathrm{b}}$ & $22.44 \pm 7.42^{\mathrm{a}}$ \\
\hline & Conventional & $41.27 \pm 1.48^{\mathrm{a}}$ & $11.08 \pm 0.61^{\mathrm{b}}$ & $7.03 \pm 0.83^{b}$ & $13.14 \pm 0.77^{b}$ & $32.32 \pm 3.05$ & $4.21 \pm 0.53^{\mathrm{c}}$ \\
\hline \multirow[t]{3}{*}{ Heart } & Organic & $40.67 \pm 2.98^{\mathrm{a}}$ & $9.74 \pm 1.34^{\mathrm{c}}$ & $6.40 \pm 1.42^{\mathrm{b}}$ & $11.74 \pm 1.30^{\mathrm{c}}$ & $33.30 \pm 7.44$ & $7.66 \pm 0.46^{\mathrm{b}}$ \\
\hline & Wild & $37.39 \pm 2.81^{\mathrm{b}}$ & $12.99 \pm 1.51^{\mathrm{a}}$ & $8.52 \pm 1.57^{\mathrm{a}}$ & $15.55 \pm 2.01^{\mathrm{a}}$ & $33.03 \pm 3.30$ & $9.23 \pm 2.25^{\mathrm{a}}$ \\
\hline & Conventional & $35.19 \pm 1.45^{\mathrm{a}}$ & $7.69 \pm 0.52^{\mathrm{a}}$ & $3.91 \pm 0.35^{\mathrm{a}}$ & $8.64 \pm 0.49^{\mathrm{a}}$ & $26.98 \pm 2.64^{\mathrm{ab}}$ & $3.85 \pm 0.63^{b}$ \\
\hline \multirow[t]{2}{*}{ Gizzard } & Organic & $31.35 \pm 1.75^{b}$ & $5.89 \pm 0.75^{\mathrm{b}}$ & $2.94 \pm 0.64^{\mathrm{b}}$ & $6.60 \pm 0.90^{\mathrm{b}}$ & $26.33 \pm 3.51^{b}$ & $4.59 \pm 1.05^{\mathrm{b}}$ \\
\hline & Wild & $31.47 \pm 1.75^{\mathrm{b}}$ & $6.75 \pm 1.30^{\mathrm{a}}$ & $3.72 \pm 0.92^{\mathrm{a}}$ & $7.72 \pm 1.57^{\mathrm{a}}$ & $28.62 \pm 2.42^{\mathrm{a}}$ & $6.80 \pm 0.57^{\mathrm{a}}$ \\
\hline
\end{tabular}

Values in the same column with different superscripts ${ }^{\mathrm{a}, \mathrm{b}, \mathrm{c}}$ are significantly different $(P<0.05)$ between conventional, organic, and wild ducks; HP - content of haem pigments

Table 3. Chemical composition of giblets (mean $\pm \mathrm{SD}$ ) (gizzard, heart, and liver) from conventional, organic and wild ducks ( $\mathrm{n}=24$ /group).

\begin{tabular}{|c|c|c|c|c|c|c|c|}
\hline Giblet & Type of duck & $\begin{array}{c}\text { Dry matter } \\
(\%)\end{array}$ & $\begin{array}{c}\text { Total protein } \\
(\%)\end{array}$ & $\begin{array}{l}\text { Fat } \\
(\%)\end{array}$ & $\begin{array}{l}\text { Ash } \\
(\%)\end{array}$ & $\begin{array}{c}\text { Carbohydrate } \\
(\%)\end{array}$ & $\begin{array}{c}\text { Energy value } \\
(\mathrm{Kj} / 100 \mathrm{G})\end{array}$ \\
\hline \multirow{3}{*}{ Liver } & Conventional & $28.27 \pm 0.78^{b}$ & $21.42 \pm 0.71^{\mathrm{a}}$ & $2.42 \pm 0.61^{\mathrm{a}}$ & $1.39 \pm 0.04^{\mathrm{b}}$ & $3.10 \pm 0.90^{\mathrm{b}}$ & $\overline{505.09 \pm 19.29^{\mathrm{a}}}$ \\
\hline & Organic & $28.42 \pm 0.59^{\mathrm{b}}$ & $22.20 \pm 0.51^{\mathrm{a}}$ & $0.59 \pm 0.26^{\mathrm{b}}$ & $1.58 \pm 0.06^{\mathrm{a}}$ & $4.05 \pm 0.69^{\mathrm{b}}$ & $468.94 \pm 9.14^{\mathrm{b}}$ \\
\hline & Wild & $29.70 \pm 1.16^{\mathrm{a}}$ & $16.56 \pm 1.37^{\mathrm{b}}$ & $0.77 \pm 0.44^{b}$ & $1.23 \pm 0.06^{\mathrm{c}}$ & $11.14 \pm 2.40^{\mathrm{a}}$ & $499.26 \pm 21.21^{\mathrm{a}}$ \\
\hline \multirow{3}{*}{ Heart } & Conventional & $25.24 \pm 2.03^{b}$ & $15.49 \pm 0.63^{c}$ & $4.31 \pm 1.45^{\mathrm{b}}$ & $1.06 \pm 0.02^{\mathrm{b}}$ & $4.38 \pm 1.95^{\mathrm{a}}$ & $497.38 \pm 55.44^{b}$ \\
\hline & Organic & $28.19 \pm 0.83^{\mathrm{a}}$ & $16.60 \pm 0.35^{\mathrm{b}}$ & $8.88 \pm 1.47^{\mathrm{a}}$ & $1.01 \pm 0.05^{\mathrm{c}}$ & $1.70 \pm 1.18^{\mathrm{b}}$ & $639.55 \pm 37.29^{a}$ \\
\hline & Wild & $26.30 \pm 0.32^{\mathrm{b}}$ & $17.75 \pm 0.19^{\mathrm{a}}$ & $2.64 \pm 0.67^{\mathrm{c}}$ & $1.12 \pm 0.03^{\mathrm{a}}$ & $4.80 \pm 0.64^{\mathrm{a}}$ & $480.84 \pm 15.04^{\mathrm{b}}$ \\
\hline \multirow{3}{*}{ Gizzard } & Conventional & $23.17 \pm 0.55^{\mathrm{c}}$ & $18.67 \pm 0.43^{\mathrm{c}}$ & $0.59 \pm 0.15^{b}$ & $0.99 \pm 0.04$ & $2.92 \pm 0.37$ & $388.86 \pm 11.27^{b}$ \\
\hline & Organic & $24.79 \pm 0.77^{b}$ & $19.56 \pm 0.42^{\mathrm{b}}$ & $1.23 \pm 0.50^{\mathrm{a}}$ & $0.97 \pm 0.14$ & $3.03 \pm 0.78$ & $429.71 \pm 22.31^{\mathrm{a}}$ \\
\hline & Wild & $25.60 \pm 0.69^{\mathrm{a}}$ & $21.57 \pm 0.70^{\mathrm{a}}$ & $0.80 \pm 0.32^{\mathrm{b}}$ & $0.98 \pm 0.03$ & $2.38 \pm 0.74$ & $434.64 \pm 13.50^{\mathrm{a}}$ \\
\hline
\end{tabular}

Values in the same column with different superscripts ${ }^{a, b}, c$ are significantly different $(\mathrm{P}<0.05)$ between conventional, organic, and wild ducks. 
amount of dry matter and carbohydrate. Generally, the total protein, ash, and carbohydrate content in the hearts of $\mathrm{W}$ ducks were the highest, while the fat percentage and energy value were the lowest. The hearts of ducks from the $\mathrm{C}$ system contained significantly $(P<0.05)$ the lowest amount of total protein. The fat content in the heart tissue of $\mathrm{O}$ ducks was significantly $(P<0.05)$ the highest. The results of our analysis show that a lower percentage of dry matter, total protein, fat content and energy value were observed in the gizzard of ducks from the $\mathrm{C}$ system.

\section{Discussion}

\section{Production properties}

Our study did not find significant $(P<0.05)$ differences between $\mathrm{C}$ and $\mathrm{O}$ ducks regarding live weight, carcass weight, and yield. In line with this finding, Wang et al. (2009) indicated that no significant difference was observed in dressing percentage between chickens from free-range and conventional systems. In contrast, several pieces of research (Dong and Ogle 2000; Rembialkowska and Badowski 2012; Kolluri et al. 2015; Abdullah and Buchtova 2016) have indicated poor growth and body weight of poultry under organic, free range, and extensive rearing systems due to higher activity and more energy consumption related to body thermoregulation. This hypothesis could apply even more to $\mathrm{W}$ ducks, according to the results of our study. Moreover, the poor weight of $\mathrm{W}$ ducks is usually compared to that of $\mathrm{C}$ ducks, whereas the low yield of eviscerated carcasses could also be attributed to the technological process used on the animal body (skinning).

The higher weight and yield of giblets from $\mathrm{O}$ ducks compared to $\mathrm{C}$ ducks are in agreement with previous studies on chicken (Adedeji et al. 2014; Abdullah and Buchtová 2016). According to Murawska et al. (2011), there is an inverse relationship between muscle tissue weights and the percentage content of giblets during the growing process in chicken. This idea could explain the highest percentage of giblets in W ducks in our study. Gizzards from $\mathrm{O}$ ducks of higher weight and yield could be attributed to the nature of feeding (access to a grassy paddock and swimming pond) which can include various kinds of plant and animals as well as sand particles. Furthermore, a diet rich in crude fibre, which is usual for poultry feeding in an organic and free-range system, could be the reason for stimulation of gizzard development (Dou et al. 2009).

\section{Colour indicators and haem pigment content}

The colour of meat could be influenced by environmental conditions (feeding and housing) and animal welfare (pre-slaughter stress) (Du and Ahn 2002; Castellini et al. 2002) as well as other factors such as myoglobin concentration, degree of oxidation and the structure of the meat (Abdullah and Buchtová 2020; Ruiz de Huidobro et al. 2005). The darker colour of giblets from W ducks could be attributed to poor bleeding which is usual in game animals. The lower lightness values ( $\mathrm{L} *$ indicators) of $\mathrm{O}$ giblets compared to C giblets were also observed in chickens in our previous study (Abdullah and Buchtová 2016). Several studies (Fanatico et al. 2007; Mikulski et al. 2011; Chen et al. 2013) have found that the outdoor access provided to poultry by the organic system influenced the lightness of meat and led to the production of darker meat. However, many factors influence lightness indicators ( $\mathrm{L}^{*}$ value), such as $\mathrm{pH}$, the structure of myofibrils and the water-holding capacity of meat (Fletcher 1999). Trampel et al. (2005) suggested that the lighter colour of liver is related to its high total lipid content, which corresponded with the results for the liver fat content in our study (Table 3 ).

The greater redness of giblets from $\mathrm{W}$ ducks could be ascribed to less bleeding and a higher haem pigment content. The less red colour of giblets from ducks from the organic system could be attributed to low $\mathrm{pH}_{\mathrm{ult}}$, which decreases the importance of the role played 
by myoglobin in selectively absorbing green light (Castellini et al. 2002). The livers of ducks that were bred conventionally in this study were more yellow than the livers of $\mathrm{O}$ and $\mathrm{W}$ ducks, which might be attributed to their higher lipid content (Table 3) as a result of lipophilic pigment storage (Sirri et al. 2010). In our previous study (Abdullah and Buchtová 2016) we reported results for the giblets of organic chicken similar to the present results of a lower yellow colour indicator $\left(b^{*}\right)$ in giblets from $\mathrm{O}$ ducks. It is, however, necessary to monitor many factors that could play a role in the colour of giblets, such as duck nutrition, animal welfare (stress conditions), bleeding sufficiency and the $\mathrm{pH}$ of samples.

\section{Chemical composition}

There is very limited published information regarding this topic and we did not find any similar published results to compare with our study. Generally, the liver and gizzard of all three groups of ducks contain more protein, whereas the heart is fattier. The gizzards had a lower energy value compared to the other organs. The results for the chemical composition of the liver from ducks from the organic rearing system show that it was more nutritionally valuable (higher protein and ash content, and lower fat and energy value) relative to the livers of $\mathrm{C}$ and $\mathrm{W}$ ducks. The liver of organic chicken also contains higher total protein and ash than that of conventional broilers (Abdullah and Buchtová 2016). As previously explained (Abdullah and Buchtová 2016), the possibility of organic poultry ingesting organic and inorganic substances from soil is probably the reason for the higher ash content in their liver. However, the liver of $\mathrm{W}$ ducks evaluated by Cobos et al. (2000) contained less dry matter $(27.18 \%)$ and higher protein $(18.1 \%)$, fat $(5.47 \%)$ and ash $(1.53 \%)$.

Higher protein and lower fat content in the hearts of $\mathrm{W}$ ducks could be attributed to the high motor activity behaviour of such birds in the wild. This hypothesis could also apply to poultry in the organic rearing system, where the birds have a higher standard of welfare with higher levels of motor activity in a free-range area (outdoor access). Greater locomotor activity in birds prioritises the process of myogenesis over lipogenesis in the muscles (Castellini et al. 2002; Abdullah and Buchtová 2016; Abdullah and Buchtová 2017).

The coarse nature of the feed of $\mathrm{W}$ ducks could have an effect on the muscular tissue development of the gizzard, thereby elevating its protein content and reducing its lipid ratio. Karunajeewa and Tham (1984) suggested that poultry fed a coarser feed required more grit stone to increase the activity of the gizzard. In contrast to these results, no significant differences were observed in dry matter, total protein, and fat content between gizzards from chickens from organic and conventional production systems (Abdullah and Buchtová 2016). Comparing our results for $\mathrm{C}$ duck gizzards with the results published by $\mathrm{Ku}$ et al. (2013), the protein percentage was lower (18.67 vs. 20.20), while the ratio of the dry matter $(23.17$ vs. 21.68$)$, fat ( 0.59 vs. 0.57$)$ and ash $(0.99$ vs. 0.90$)$ content was higher.

The nutritional value and colour of meat, meat products, and edible by-products play an important role in consumer purchase decisions. The results of this study may provide information on the quantitative and qualitative properties of duck giblets to researchers and consumers, as such information is extremely scarce. The study found differences in production properties, colour indicators, and chemical composition between giblets (liver, heart, and gizzard) from $\mathrm{C}, \mathrm{O}$, and $\mathrm{W}$ ducks. The darker colour, greater redness, and higher haem pigment content in giblets from $\mathrm{W}$ ducks could be attributed to poor bleeding of the hunted animals compared to the more complete bleeding by exsanguination in $\mathrm{O}$ and $\mathrm{C}$ ducks at the slaughterhouse. The livers of $\mathrm{C}$ ducks were lighter (higher $\mathrm{L}^{*}$ value), more yellow (higher $b^{*}$ value) and fatter (higher fat content) than the livers of both the other evaluated groups of ducks. The livers of $\mathrm{O}$ ducks and the hearts of $\mathrm{W}$ ducks were superior (higher protein and ash content on one hand and lower fat content and energy value on the 
other) in terms of nutritional value for the consumer, according to the results of chemical composition. However, this topic requires more extensive study from various aspects in order to provide information regarding the edible by-product organs for consumers and researchers.

\section{Acknowledgment}

Financial support for this study was provided by the University of Veterinary Sciences Brno, Palackeho tr. 1, 61242 Brno, Czech Republic (FVHE/Tremlova/ITA2019).

\section{References}

Abdullah FAA, Buchtová H 2016: Comparison of qualitative and quantitative properties of the wings, necks and offal of chicken broilers from organic and conventional production systems. Vet Med 61: 643-651

Abdullah FAA, Buchtová H 2017: Quantity and quality properties of breast and thigh of chicken broilers from organic and conventional production systems. Arch Lebensm.hyg 68: 53-80

Abdullah FAA, Buchtová H 2020: Selected freshness indices of skin and wings from organic chicken packaged in modified atmosphere. Acta Vet Brno 89: 97-105

Adedeji OS, Amao SR, Oguntunde MM, Dada ID 2014: evaluation of general performance and carcass qualities of organically raised broiler chickens from day old to 12 weeks of age. Int J Agric Innov Res 2: 466-471

Alvarez-Astorga M, Capita R, Alonso-Calleja C, Moreno B, Garcia-Fernandez C 2002: Microbiological quality of retail chicken by-products in Spain. Meat Sci 62: 45-50

Anonymous 2021: Czech Republic duck meat market insights. Selina Wamucii. Available at: https://www. selinawamucii.com/insights/market/czech-republic/duck-meat/. Accessed September 2, 2021

Biswas S, Banerjee R, Bhattacharyya D, Patra G, Das AK, Das SK 2019: Technological investigation into duck meat and its products - a potential alternative to chicken. Worlds Poult Sci J 75: 609-620

Castellini C, Mugnai C, Dal Bosco A 2002: Effect of organic production system on broiler carcass and meat quality. Meat Sci 60: 219-225

Chen X, Jiang W, Tan HZ, Xu GF, Zhang XB, Wei S, Wang XQ 2013: Effects of outdoor access on growth performance, carcass composition, and meat characteristics of broiler chickens. Poult. Sci 92: 435-443

Cobos A, Veiga A, Diaz O 2000: Chemical and fatty acid composition of meat and liver of wild ducks (Anas platyrhynchos). Food Chem 68: 77-79

Commission Regulation 2008: (EC) No 889/2008 laying down detailed rules for the implementation of Council Regulation (EC) No 834/2007 on organic production and labelling of organic products with regard to organic production, labelling and control. OJ: L 250: 1-84

Darine S, Christophe V, Gholamreza D 2010: Production and functional properties of beef lung protein concentrates. Meat Sci 84: 315-322

Dong NTK, Ogle RB 2000: Effect of brewery waste replacement of concentrate on performance of local and crossbred growing Muscovy ducks. In: Proceedings of "Making better use of local feed resources" SAREC$\mathrm{UAF}$

Dou TC, Shi SR, Sun HJ, Wang KH 2009: Growth rate, carcass traits and meat quality of slow-growing chicken grown according to three raising systems. Anim Sci Pap Rep 27: 361-369

Du M, Ahn DU 2002: Effect of dietary conjugated linoleic acid on the growth rate of live birds and on the abdominal fat content and quality of broiler meat. Poult Sci 81: 428-433

Fanatico AC, Pillai PB, Emmert JL, Owens LM 2007: Meat quality of slow- and fast-growing chicken genotypes fed low-nutrient or standard diets and raised indoors or with outdoor access. Poult Sci 86: 2245-2255

Faostat 2021: Livestock primary, production quantity, duck meat, 2000 and 2019, Available at: http://www.fao. org/, accessed January 2021

Fletcher DL 1999: Broiler breast meat color variation, pH, and texture. Poult Sci 9: 1323-1327

Hornsey HC 1956: The colour of cooked cured pork. I.- Estimation of the nitric oxide-haem pigments. J Sci Food Agr 7: 534-540

ISO 1442 1997: Meat and meat products - Determination of moisture content (Reference method). Czech National Standard CSN, Czech Republic

ISO 1443 1973: Meat and meat products - Determination of total fat (Reference method). Czech National Standard CSN, Czech Republic

ISO 936 1978: Meat and meat products - Determination of total ash (Reference method). Czech National Standard CSN, Czech Republic

ISO 937 1978: Meat and meat products - Determination of nitrogen content (Reference method). Czech National Standard CSN, Czech Republic

Izumimoto M 1976: Direct method for assay of haem-pigment in muscle and its application. Nippon Nogeikagaku Kaishi. Japan Soc Biosci Biotech Agrochem 50: 55-59

Karunajeewa H, Tham SH 1984: Choice feeding of the replacement pullet on whole wheat grains and subsequent performance on laying diets. Br Poult Sci 25: 99-109 
Kokoszynski D, Wilkanowska A, Arpášová H, Hrncár C 2020: Comparison of some meat quality and liver characteristics in Muscovy and mule ducks. Arch Anim Breed 63: 137-144

Kolluri G, Ramamurthy N, Churchil RR, Sundaresan A, Gawdaman G 2015: Carcass studies in native ducks reared under different housing systems. Ind J Vet \& Anim Sci Res 44: 01-11

Kowalska AS, Gurkowa K, Kovarník J 2020: Organic Farming in Poland and the Czech Republic - Comparative Analysis, In: Jedlicka P (Eds.): Proceedings of the International Scientific Conference Hradec Economic Days 2020, University of Hradec Kralove, pp. 373-381

Ku SK, Hwang SH, Lim SD, Lee KH, Kim YB 2013: Nutritional characteristics and quality changes of duck byproducts during frozen storage at $-20^{\circ} \mathrm{C}$. J Korean Soc Food Sci Anim Resour 33:109-118

Mancinelli AC, Mattioli S, Dal Bosco A, Ciarelli C, Castellini C 2020: Grass intake and meat oxidative status of geese reared in three different agroforestry systems. Acta fytotechn zootechn 23: 308-315

Massuquetto A, Panisson JC, Schramm VG, Surek D, Krabbe EL, Maiorka A 2020: Effects of feed form and energy levels on growth performance, carcass yield and nutrient digestibility in broilers. Animal 14: 1139-1146

Mikulski D, Celej J, Jankowski J, Majewska T, Mikulska M 2011: Growth performance, carcass traits and meat quality of slower-growing and fast-growing chickens raised with and without outdoor access. Asian-Australas J Anim Sci 24: 1407-1416

Murawska D, Kleczek K, Wawro K, Michalik D 2011: Agerelated changes in the percentage content of edible and non-edible components in broiler chickens. Aust J Agric Res 24: 532-539

Regulation 2011. (EU) No 1169/2011 on the provision of food information to consumers, annex XIV. OJ: L 304: 18-63

Rembialkowska E, Badowski M 2012: Nutritional value of organic meat and potential human health response. In: Ricke SC, Van Loo EJ, Johnson MG, O’Bryan CA (Eds): Organic Meat Production and Processing. 1st edn. Wiley Scientific/IFT, New York. 239-252

Ruiz de Huidobro F, Miguel E, Blazquez B, Onega E 2005: A comparison between two methods (Warner-Bratzler and texture profile analysis) for testing either raw meat or cooked meat. Meat Sci 69: 527-536

Saláková A, Straková E, Válková V, Buchtová H, Steinhauserová I 2009: Quality indicators of chicken broiler raw and cooked meat depending on their sex. Acta Vet Brno 78: 497-504

Šejnohová H, Babáčková J, Hlaváčková J, Warthová S 2021: Report on the organic food market in the Czech Republic in 2019. (In Czech). Institute of Agricultural Economics and Information, Brno, Czech Republic, Available at: http://eagri.cz/public/web/file/676190/Zprava_o_trhu_s_biopotravinami_v_CR_v_roce_2019. pdf, accessed September 1, 2021

Seong PN, Cho SH, Park KM, Kang GH, Park BY, Moon SS, Ba HV 2015: Characterization of chicken byproducts by mean of proximate and nutritional compositions. Korean J Food Sci An 35: 179-188

Sirri F, Castellini C, Roncarati A, Franchini A, Meluzzi A 2010: Effect of feeding and genotype on the lipid profile of organic chicken meat. Eur J Lipid Sci Technol 112: 994-1002

Trampel DW, Sell JL, Ahn DU, Sebranek JG 2005: Preharvest feed withdrawal affects liver lipid and liver color in broiler chickens. Poult Sci 84: 137-142

Wang KH, Shi SR, Dou TC, Sun HJ 2009: Effect of a freerange raising system on growth performance, carcass yield, and meat quality of slow-growing chicken. Poult Sci 88: 2219-2223

Zelenka J 2014: Poultry nutrition and feeding. (in Czech). Vydavatelstvi Agriprint, 1st edn, Olomouc, 160 p. 